

Proceedings of the Estonian Academy of Sciences,

$2021,70,2,207-214$

https://doi.org/10.3176/proc.2021.2.09

Available online at www.eap.ee/proceedings

MITIGATION OF

SEAL-FISHERY

CONFLICT

\title{
Seal-induced losses and successful mitigation using Acoustic Harassment Devices in Estonian Baltic trap-net fisheries
}

\author{
Markus Vetemaa ${ }^{\mathrm{a}^{*}}$, Ulvi Päädam ${ }^{\mathrm{a}}$, Arne Fjälling ${ }^{\mathrm{b}}$, Mehis Rohtla $^{\mathrm{a}}$, Roland Svirgsden ${ }^{\mathrm{a}}$, Imre Taal ${ }^{\mathrm{a}}$, \\ Aare Verliin ${ }^{\mathrm{a}}$, Redik Eschbaum ${ }^{\mathrm{a}}$ and Lauri Saks ${ }^{\mathrm{a}}$

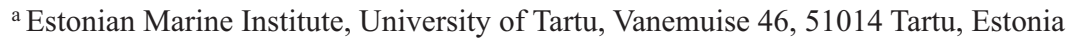 \\ ${ }^{\mathrm{b}}$ Department of Aquatic Resources, Swedish University of Agricultural Sciences, Stångholmsvägen 2, 17893 Drottningholm, Sweden
}

Received 9 December 2020, accepted 20 April 2021, available online 18 May 2021

(C) 2021 Authors. This is an Open Access article distributed under the terms and conditions of the Creative Commons AttributionNonCommercial 4.0 International License (http://creativecommons.org/licenses/by-nc/4.0/).

\begin{abstract}
During the last decades the number of grey seals Halichoerus grypus has increased more than tenfold in the Baltic Sea, having reached 38000 in 2019, which has created increasing problems to the coastal fisheries. In the current study, 151 Estonian coastal fishermen were interviewed to sum all direct and indirect monetary losses. The total cost of the damage caused by seals to the Estonian fisheries was around 0.9 million euros in 2009. With the aim of mitigating seal impact, Acoustic Harassment Devices (AHDs, Lofitech) were tested. This study presents quantitative data on seal damage in Estonian trap-net fisheries and analyses the results of the attempts made to mitigate the damage by means of AHDs. It can be concluded that AHDs provided sufficient protection against the seal attacks.
\end{abstract}

Key words: Acoustic Harassment Devices, coastal fisheries, trap nets, catch damage, Baltic Sea, grey seal.

\section{INTRODUCTION}

Following the ban of several harmful substances (DDT, PCB, etc.), the number of grey seals Halichoerus grypus in the Baltic Sea has grown more than tenfold from ca 2000 in the 1970 s to ca 38000 counted seals in 2019 (HELCOM 2020). In parallel, seal-induced gear and catch damage has increased dramatically (Westerberg et al. 2000; Jounela et al. 2006; Königson et al. 2007; Königson et al. 2009). If compared to other Baltic fisheries, the problem is most severe in the coastal gill-net and trap-net fisheries for salmon Salmo salar, sea trout Salmo trutta and whitefish Coregonus lavaretus, where grey seals frequently visit the traps (Lehtonen and Suuronen 2004).

By the total catch value, the most important segment of the Estonian coastal fisheries is the trap-net fishery targeting spring-spawning herring Clupea harengus membras

\footnotetext{
*Corresponding author, markus.vetemaa@ut.ee
}

and garfish Belone belone (Vetemaa et al. 2006). This type of gear, often referred to as a pound net, is rather large (up to $20 \mathrm{~m} \times 20 \mathrm{~m}$ ) and open above. To enable the entering of schooling pelagic fish, the gates are quite wide. As a consequence, seals can enter these traps very easily through the gates and over the side panels. It is practically impossible to use grids or other technical modifications to protect the catch.

Since the monetary losses severely impact fisheries, there is an acute need for solutions that could prevent or discourage seals from entering the traps, where they eat catch or scare it out. Another way to address the problem is by the removal of so-called "problem seals", animals specializing in raiding e.g. salmon traps (Graham et al. 2011; Königson et al. 2013; Suuronen and Lehtonen 2012). However, a seal hunt to protect gear and reduce problems in fisheries (Finland, Sweden and Estonia started seal hunt in 1998, 2001 and 2015, respectively) has been rather limited, much below the hunt quota, and therefore it has 
not resolved the problem with seal-induced catch losses, nor has it had a significant effect on the population growth (Kauhala et al. 2015). Thus, one of the few potential possibilities to keep the fishery economically viable is to use underwater Acoustic Harassment Devices (AHDs) which produce sounds of sufficiently high intensity to cause discomfort or pain in the seals, and hence lead to avoidance (Westerberg et al. 2006). However, the effects of AHDs on catch losses and gear damage in fisheries have previously been investigated only in few studies (Mate and Harvey 1986; Fjälling et al. 2006; Graham et al. 2009) with no clear results. At the same time, instant and timedependent effects may differ considerably between the type of the AHD, fishing gear, seal species, and many other factors (Fjälling et al. 2006).

The objective of this study was to (i) quantify Estonian nationwide economic losses caused by seals in relation to gear types and counties, (ii) evaluate the share of damaged catches in the economically most important coastal fishing operation (pound-net fishery), (iii) assess whether seals could be effectively deterred from pound nets and fyke nets and (iv) test AHDs and other necessary equipment (e.g. solar panels as the source of energy) under the opensea conditions. The tests with AHDs were carried out during several years in different Estonian areas, where the share of the reported damage to the total revenues was the highest, and the conflict most critical.

\section{MATERIAL AND METHODS}

\section{Overall economic losses}

In 2009, interviews were conducted with 151 coastal commercial fishermen along the whole Estonian coast. This sample represents approximately $10 \%$ of the total number of fishermen. However, since active fishermen with the highest catches were selected, the total catch corresponded to around $60 \%$ of the total value of the Estonian coastal fisheries. Twenty-one questions were asked, enabling detailed summarization of monetary losses due to seal-induced problems causing (i) gear damage, (ii) observed damage to catches (not hidden losses), and (iii) indirect losses such as the necessity to cease fishing activities in some areas during some periods. The reported damage was extrapolated to the whole Estonian coastal fisheries based on the detailed fishing effort statistics and average first-sell prices obtained from the Estonian Ministry of Agriculture.

\section{The effectiveness of AHDs in trap-net fisheries}

In order to test the usability of AHDs under varying natural conditions, trials were carried out during four fishing seasons (2011-2014) in the Gulf of Riga (Saaremaa county, sites A and B, and Pärnumaa county, site C) and the Gulf of Finland (Ida-Virumaa county, site D) (Fig. 1). The data on the duration of each test is presented with the results below. The AHDs used in the current study were produced by Lofitech (www.Lofitech.no). These devices emit bursts of pulses of 250-500 ms (selectable duration; in order to save power, $250 \mathrm{~ms}$ was selected); work at a frequency of $15 \mathrm{kHz}$ and at a source level of $179 \mathrm{~dB}$ re $1 \mu \mathrm{Pa} \mathrm{rms} \mathrm{m}{ }^{-1}$ (data provided by the producer). The interval of bursts was 1.5 minutes (Units 1 and 2) and 2 minutes (Units 3, 4 and 5).

AHDs were placed into semi-waterproof (IP 67) boxes (www.peli.com) and mounted to a boat (Units 1 and 2) or to a floating raft (Units 3, 4 and 5) and anchored in the close vicinity $(10-20 \mathrm{~m})$ of the fishing gear in the respective study sites. The power to the AHDs was channelled via a $400 \mathrm{~m}$ long under-water cable (Unit 1), by two local 12 V 120 Ah (PB SunnyWay) deep-cycle batteries (Unit 2, batteries were charged every third day), or by solar panels backed up by one 12 V 120 Ah (PB SunnyWay) local deep-cycle battery (Units 3, 4 and 5) (Fig. 2).

AHDs were deployed to protect the catch in pound nets in site A and fyke nets in sites $\mathrm{C}$ and D. Pound nets

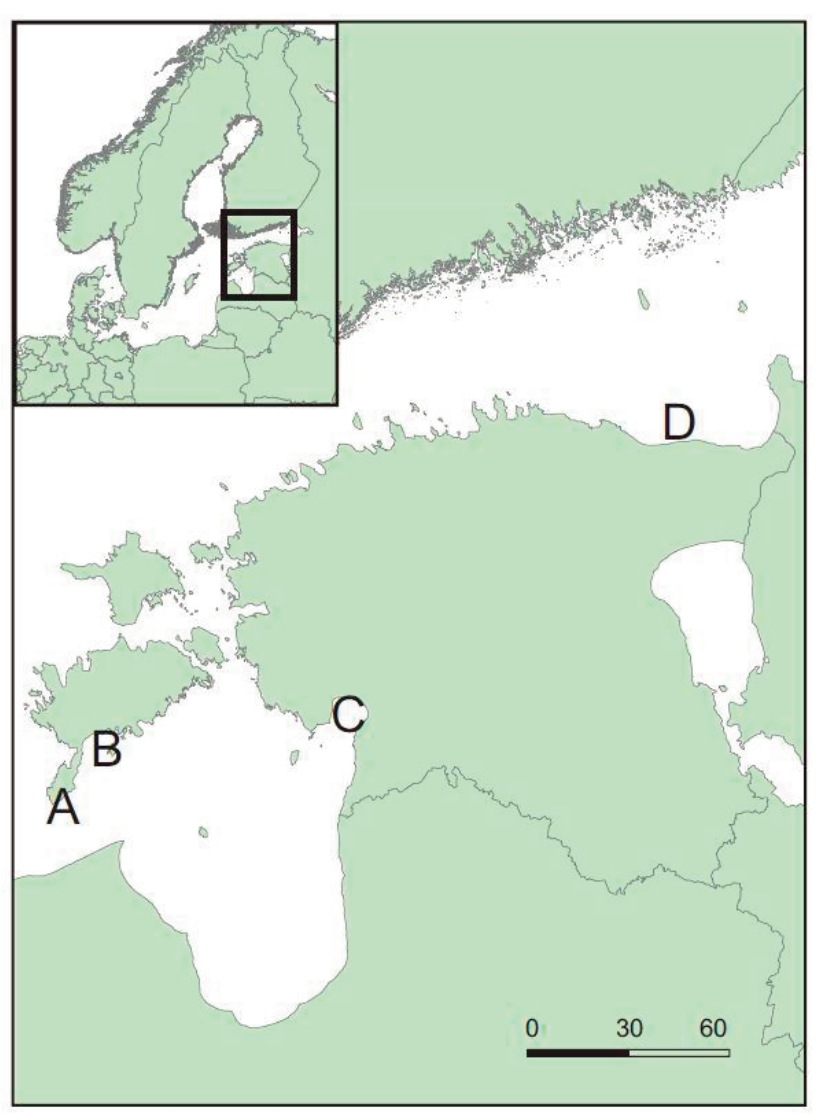

Fig. 1. The study sites. 


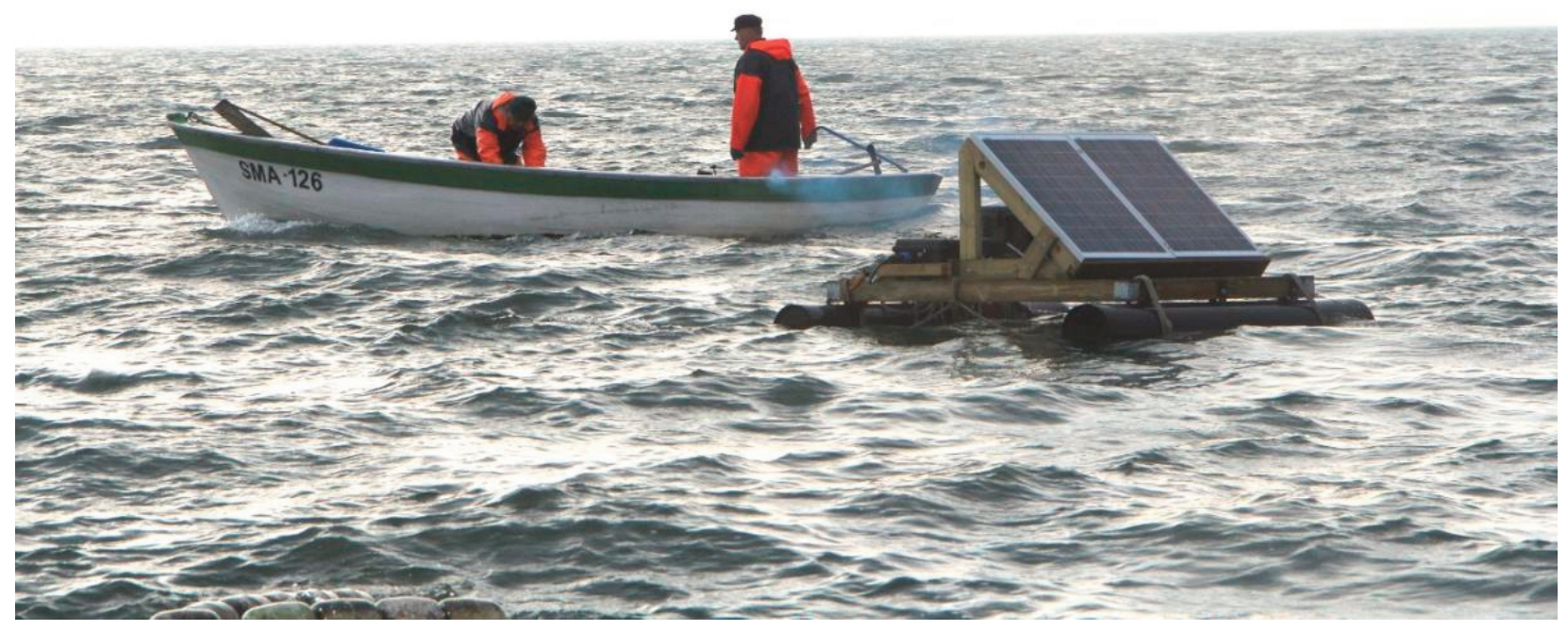

Fig. 2. AHD Unit 3.

(Sainsbury 1996) are large open-top trap nets (the fishkeeping part measuring around $10 \mathrm{~m} \times 10 \mathrm{~m}$ horizontally, and the height depending on the water depth, ranging from $3 \mathrm{~m}$ to $8 \mathrm{~m}$ ) targeting schooling fish, such as herring and garfish. In the peak fishing season, a pound net can catch up to several tons of fish daily. Fyke nets have a mouth size of $3 \mathrm{~m}$ and are funnel-type, i.e. round plastic hoops are covered with netting, and fish can be removed from the rear by loosening the securing line to open the end (Sainsbury 1996). The seal-safe gear in locality C was made of super-strong polyethylene material Dyneema, which has been proved to resist grey seal attacks (Hemmingsson et al. 2008). In locality C all the three tested gear had the same size and construction. The hypothesis that the use of AHDs results in larger catches as seals are effectively deterred from the immediate vicinity of the gear was tested by comparing catches from the AHD protected and unprotected gear using Friedman ANOVA and Wilcoxon Matched Pairs tests (sites A and C) when the gear with and without the AHD was hauled during the same day and using the Mann-Whitney U-test when the gear with and without the AHD was hauled independently from each other (site D).

\section{The proportion of damaged catch in the unprotected pound-net fisheries}

The proportion of damaged garfish catch was estimated in four pound nets not protected by AHDs during the spring fishing season of 2011 (35 days) in site B (Fig. 1). All the gear was operated by the same fishermen, and the results gained from all the gear of these fishermen were included in the study. Unit 2 was initially deployed in site $\mathrm{B}$, attached to one of the pound nets in this site, but since the changing of batteries was too laborious to the fisher- men operating this gear, the AHD was removed only after eight days. The data collected during this short time was estimated to be too limited, and is therefore not presented in the current paper.

Typically, seals eat the body of the garfish in a pound net and leave the heads in the gear. The heads were counted and the weight of the damaged catch was calculated from the average weight of the intact landed specimens. Based on the head size, it was assumed that the weight of the average damaged and intact fish was the same. Each haul was considered a sampling event. The hypothesis that the proportion of damaged catch is associated with the amount of fish in the gear was tested with the G-test of independence.

\section{RESULTS}

\section{Total economic losses}

Only few fishermen reported no seal-caused losses. For most, seals were deemed to create serious economic losses. The monetary values by the three main types of seal-induced losses (gear damage, catch damage, indirect losses) are shown in Table 1. Losses by the three main types of fishing gear compared to the total fishing revenues by the Estonian coastal counties are presented in Table 2.

\section{The proportion of damaged catch in unprotected trap-net fisheries}

In non-protected pound nets (site B) the proportion of damaged catch ranged from $25.00 \%-46.95 \%$ (Fig. 3) between different traps when all the seasonal data was 
Table 1. Calculated monetary losses (in thousand euros) caused by seals in coastal counties in 2009. The bulk of the indirect losses corresponds to interrupted fishing activities

\begin{tabular}{l|c|c|c|c}
\hline \multicolumn{1}{c|}{ County } & Gear damage & $\begin{array}{c}\text { Catch } \\
\text { damage }\end{array}$ & $\begin{array}{c}\text { Indirect } \\
\text { losses }\end{array}$ & Total loss \\
\hline Harju & 42.8 & 42.8 & 9.6 & 95.2 \\
Hiiu & 14.1 & 11.5 & 0.6 & 26.2 \\
Ida-Viru & 10.2 & 92.7 & 8.9 & 111.8 \\
Lääne & 24.3 & 10.2 & 7.0 & 41.5 \\
Lääne-Viru & 8.3 & 7.0 & 5.1 & 20.5 \\
Pärnu & 108.0 & 309.3 & 73.5 & 490.8 \\
Saare & 15.3 & 36.4 & 21.1 & 72.9 \\
Total & 223.0 & 510.0 & 125.9 & 859.0
\end{tabular}

Table 2. Revenues and calculated losses (in thousand euros) by fishing gear and counties in Estonian coastal fisheries in 2009

\begin{tabular}{l|c|c|c|c|c|r|r|r}
\hline $\begin{array}{c}\text { Coastal } \\
\text { county }\end{array}$ & $\begin{array}{c}\text { Fyke net } \\
\text { revenue }\end{array}$ & $\begin{array}{c}\text { Fyke net } \\
\text { losses }\end{array}$ & $\begin{array}{c}\text { Pound } \\
\text { net } \\
\text { revenue }\end{array}$ & $\begin{array}{c}\text { Pound } \\
\text { net } \\
\text { losses }\end{array}$ & $\begin{array}{c}\text { Gill } \\
\text { net } \\
\text { revenue }\end{array}$ & $\begin{array}{r}\text { Gill } \\
\text { net } \\
\text { losses }\end{array}$ & $\begin{array}{r}\text { Total } \\
\text { revenue }\end{array}$ & $\begin{array}{c}\text { Total } \\
\text { losses }\end{array}$ \\
\hline Harju & 29.1 & 7.7 & 0 & 0 & 54.3 & 89.9 & 83.4 & 77.6 \\
Hiiu & 14.7 & 15.1 & 4.8 & 3.0 & 36.4 & 9.3 & 55.9 & 29.7 \\
Ida-Viru & 79.6 & 39.8 & 89.6 & 16.5 & 63.8 & 58.1 & 233.0 & 81.0 \\
Lääne & 14.3 & 10.8 & 21.0 & 0 & 35.9 & 32.3 & 71.2 & 30.6 \\
Lääne-Viru & 6.9 & 1.3 & 0 & 0 & 23.8 & 19.4 & 30.7 & 23.8 \\
Pärnu & 722.2 & 250.9 & 1177.1 & 96.2 & 892.3 & 155.0 & 2791.6 & 513.5 \\
Saare & 44.5 & 25.5 & 27.8 & 12.5 & 63.8 & 35.9 & 136.1 & 102.9 \\
Total & 911.3 & 351.1 & 1320.3 & 128.2 & 1170.3 & 399.9 & 3401.9 & 859.1
\end{tabular}



Fig. 3. Proportion of unharmed and damaged garfish in herring trap nets (without AHDs) in 2011 in locality B. summed. The proportion of damaged individuals in a catch was significantly $(\mathrm{G}=103.6$; d.f. $=3 ; \mathrm{p}<0.000001)$ lower in the gear where the total amount of fish was higher (Fig. 3).

\section{The effectiveness of AHDs}

In 2011 in locality A two pound nets (one with AHD Unit 1 and one without) were placed at a distance of $1 \mathrm{~km}$ from each other, while all other parameters (water depth, gear size, distance from the shore, openness to winds) were similar, enabling comparison. The same procedure was repeated in 2013 with Unit 3 in the same locality under similar circumstances. The length of the fishing period was 41 and 85 days in spring-summer 2011 (April-May) and 2013 (May-July), respectively. Catches were higher in the gear with the AHD in both years (Table 3) for herring (Wilcoxon Matched Pairs Test in $2011-Z=2.60$, $\mathrm{n}=11, \mathrm{p}=0.009 ;$ in $2013-\mathrm{Z}=2.14, \mathrm{n}=26, \mathrm{p}=0.032$ ) 
Table 3. Catch (kg, only unharmed fish), number of fishing days, and monetary value of two pound nets during the 2011 and 2013 spring fishing seasons in locality A

\begin{tabular}{lcccccc}
\hline & Year & Fishing days & Herring & Garfish & Total value \\
\hline Without AHD & 2011 & 41 & 1190 & 15 & 201 EUR \\
With AHD & 2011 & 41 & 3310 & 420 & 828 EUR \\
Without AHD & 2013 & 85 & 1405 & 585 & 1160 EUR \\
With AHD & 2013 & 85 & 2375 & 1125 & 2155 EUR
\end{tabular}

and garfish (Wilcoxon Matched Pairs Test in $2011-\mathrm{Z}=$ $2.52, \mathrm{n}=8, \mathrm{p}=0.012$; in $2013-\mathrm{Z}=2.61, \mathrm{n}=22, \mathrm{p}=$ $0.009)$.

In locality $\mathrm{C}$, a trap with $\mathrm{AHD}$ Unit 4, a seal-safe fyke net without an AHD, and a regular fyke net without an AHD were tested. Distances between the gear were around $0.5 \mathrm{~km}$. The test lasted 53 days in SeptemberOctober 2013. Catches per fishing season (Table 4) were the highest in the protected gear, followed by the gear made from seal-safe netting material (Friedman ANOVA $\left.\chi_{2 ; 14}^{2}=21, \mathrm{p}=0.00003\right)$.

In locality $\mathrm{D}$, two fyke nets - one with AHD Unit 5 and another without - were situated at a distance of $2 \mathrm{~km}$, while all other parameters (water depth, gear size, distance from the shore, openness to winds) were quite similar, enabling comparison. Fishing lasted for 15 days in
September 2013 and for 84 days (August-October) in 2014. Total catches per fishing season (Table 5) were significantly higher in the gear with the AHD during 2014 (Mann-Whitney U-test in $2013-\mathrm{Z}=0.63, \mathrm{n}=10, \mathrm{p}=$ 0.525 ; in $2014-\mathrm{Z}=2.00, \mathrm{n}=14, \mathrm{p}=0.043$ ).

The catches from the AHD equipped gear significantly exceeded the catches by the non-protected fishing gear when the yield was compared across all locations (Wilcoxon Matched Pairs Test: $Z=2.02, n=5, p=0.043$ ).

\section{The performance of technical equipment during field conditions}

The performance of AHDs was checked every time a catch was retrieved from the gear. The operation of AHD Units 1 and 2 was somewhat problematic, as boats tended

Table 4. Catch (kg) and its value (euros) of three fyke nets in September-October 2013 in locality B

\begin{tabular}{|c|c|c|c|c|c|c|c|c|c|c|}
\hline & 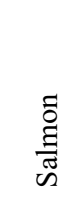 & $\begin{array}{l}\vec{\Xi} \\
\stackrel{\Xi}{\Xi} \\
\widetilde{J} \\
\tilde{S}\end{array}$ & 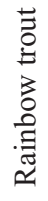 & 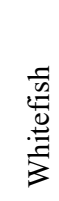 & $\begin{array}{l}\frac{1}{0} \\
\frac{0}{0} \\
\frac{2}{2} \\
\frac{\mathscr{y}}{2}\end{array}$ & 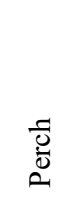 & 节 &  & 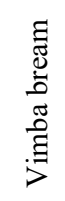 & 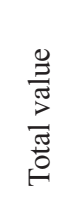 \\
\hline Fyke without AHD & 0 & 0 & 0 & 0 & 3 & 435 & 0 & 110 & 29 & 576 \\
\hline Seal-safe fyke without AHD & 59 & 28 & 0 & 0 & 9 & 2056 & 0 & 241 & 82 & 2474 \\
\hline Fyke with AHD & 521 & 150 & 7 & 56 & 50 & 3817 & 4 & 296 & 169 & 5071 \\
\hline
\end{tabular}

Table 5. Catch (kg) and its value (euros) of two fyke nets in 2013 (September) and 2014 (August-October) in locality C

\begin{tabular}{l|c|c|c|c|c|c|c|c}
\hline & Year & Perch & $\begin{array}{c}\text { Sea } \\
\text { trout }\end{array}$ & Flounder & Whitefish & Salmon & Eel & Total value \\
\hline Without AHD & 2013 & 27 & 4 & 2 & 2 & 0 & 1 & 81 \\
With AHD & 2013 & 22 & 12 & 9 & 64 & 5 & 2 & 322 \\
Without AHD & 2014 & 66 & 36 & 4 & 1 & 27 & 9 & 352 \\
With AHD & 2014 & 40 & 148 & 11 & 18 & 110 & 34 & 1141
\end{tabular}


to get soaked during the days with strong winds. In 2011, the experiment was terminated after 41 days in locality A, as excessive water in the boat resulted in a leak in the box holding AHD Unit 1, which occurred through the hole made for the cables. Since changing of the batteries for Unit 2 was too laborious as mentioned above, Unit 2 was removed already after eight days and not used any more. Units 3, 4 and 5 with solar panels mounted to the raft worked without problems in all tests.

\section{DISCUSSION}

The current study is the first in Estonia in which sealinduced losses are compiled in a quantitative way. Fjälling et al. (2006) studied seal-induced monetary losses in Sweden using eight commercial fishers, who kept detailed records of catches and seal damage to fish and gear. We employed the same method to analyse the effectiveness of AHDs and the share of damaged catches in the unprotected pound-net fisheries. However, in order to analyse the total losses in the Estonian coastal fisheries, interviews had to be used. Naturally, it is not possible to interview all, but the number of involved fishermen was relatively large, which strengthens the representability.

Estimating monetary losses is not easy as seal raids often remain unnoticed. As described by Fjälling (2005), seals sometimes leave some fish heads and damaged fish in gill nets, but most of the fish is taken completely. Therefore, we recognize that while the data gathered through interviews illustrates fairly well the proportion of visible losses by gear types and fishing areas, it likely underestimates the actual total loss. Also, while calculating gear damage, fishermen typically reported only the costs of the material (or new nets) and not the time costs for reparation of e.g. fyke nets. Thus, interviews often had to be supplemented by additional questions, which led to more exact results.

The calculation of indirect losses (mainly an interrupted fishing season due to a high abundance of seals) was the hardest part. Surprisingly, many fishermen were at first rather reluctant to give information about this, telling that "if there were no fishing, there would be no loss either". However, when the question was posed differently - "what was the typical revenue a year or two ago during the same period?" (as was pointed out by many fishermen during our contacts, in whose opinion the abundance and activity of seals increased in 2009 compared to the earlier years; consequently, many fishermen shortened their fishing seasons), information was obtained. Still, most likely this part of the loss is underestimated. According to our study, the total cost of the damage caused by seals to the Estonian coastal fisheries was around 0.9 million euros in 2009. However, as indicated above, indirect losses were not fully included, and this number should be treated as a conservative estimation. In conclusion, the total yearly seal-induced damage to the sector of Estonian coastal fisheries in 2009 could exceed one million euros. Since then, the number of grey seals in the Baltic Sea has increased by roughly 50\% (HELCOM 2020) and most likely the total loss has increased equivalently. A more recent study by Svels et al. (2019) reported that the average losses of interviewed fishermen were as follows: 20465 euros in Finland; 19834 euros in Sweden; 5451 euros in Estonia and 2562 euros in Germany.

Similarly to the current study, Fjälling et al. (2006) detected that AHDs had a positive effect by reducing the damage to catch and gear and increasing the size of undamaged catch when deployed in the salmon trap-net fisheries in the Baltic Sea. At the same time, Jacobs and Terhune (2002) reported a diminished effect of AHDs over time. In spite of these statements on the topic, there is a serious lack of studies addressing specifically habituation. Habituation of seals was not so relevant in the context of the current study with pound and fyke nets since the AHDs were placed very close to the fishing gear. Even if there are no references available, it is very likely that at the distance of less than $30 \mathrm{~m}$, AHDs generate a sound not tolerable for the seals, which means that the animals most probably chose not to raid the gear. Still, specimens with impaired hearing might habituate to feeding from the gear protected with AHDs.

The seal-fishery interaction is also causing ethical problems, since seals tend to drown in fishing nets, alarming environmentalists. However, recent data (Kauhala et al. 2015) suggests that seals drowning in the fishing gear are not a random sample of the population but they have an inferior condition, e.g. thinner blubber layer. Thus, it might even be argued that the removal of such animals affects the population less, but the number of bycaught animals is still high (Vanhatalo et al. 2014) and, therefore, the problem of bycatch has also an ethical side. Some attempts have been made to mitigate the conflict, which, besides seal hunt, includes the development of fishing technology, financial compensation and more comprehensive management approaches resorting to political measures, e.g. reaching consensus between different stakeholders like environmentalists versus fishermen (see Varjopuro 2011 and Waldo et al. 2020 for review). In addition, the spatial overlap between seals and fisheries has been studied to alleviate the negative effects of marine mammal-fishery interactions (Oksanen et al. 2014). However, the only thing that seems to help fishermen suffering losses is financial support. Therefore, technical adjustments like deployment of AHDs to protect the gear or scare away seals are still most desirable. Also, a solution in terms of a special design of the trap has been tested 
by Lunneryd et al. (2003) and later proved successful on a large scale by Hemmingsson et al. (2008). Since the introduction of this new trap in the salmon fisheries, AHDs are not used much in Swedish fisheries today, mainly because of the high price. However, due to different environmental conditions (water depth, waves and currents) and main target species (salmonids versus percids), Swedish traps cannot be adjusted to the Estonian conditions. Therefore, AHDs are still a useful alternative.

The data collected during the present study indicates that on average the minimum proportion of the lost catch to the total revenue (calculated as revenue plus lost catch) in 2009 ranged from $25 \%$ to $54 \%$ in one county (Table 2 ). This result is quite similar to the data obtained in Finland and Sweden. The Finnish Game and Fisheries Research Institute analysed the seal damage in 2001 and estimated that the proportion of the lost catch to the total revenue was $2 \%-42 \%$ (Kreivi et al. 2001). In the Kvarken region (northern Baltic Sea), the proportion of the lost catch varied between $0 \%$ and $80 \%$, depending on the location, fish species and the type of nets. On average, the assessed proportion of the lost catch was $45 \%$ (Varjopuro 2011). In Sweden, the losses in the salmon and whitefish fisheries alone were estimated to be around 1.4 million euros already in 1997. This corresponded to roughly half of the potential catch value in this segment. In 1999, the total loss in the Swedish fisheries was estimated to be around 2.5 million euros (Westerberg et al. 2000).

The effective range of an AHD depends on physical conditions, properties of the sound of the device used, and on individual characteristics of seals. Jacobs and Terhune (2002) reported that seals came as close as $45 \mathrm{~m}$ of an active AHD in the Bay of Fundy, Canada. However, the characteristics of the sound emitted by an AHD vary significantly between the manufacturers, and are of critical importance. In parallel to our tests with trap nets, gill nets were often set in the close vicinity of the AHD in locality $\mathrm{C}$. In the current study fishermen reported (detailed data not presented in this paper) that the catch at a distance of up to $200 \mathrm{~m}$ from an AHD was always unharmed, while nets more than $300 \mathrm{~m}$ away were often damaged by seals. In locality A, fishermen often observed seals escaping from the non-protected pound net shortly before the boat reached the fishing gear. While escaping seals were typical in non-protected gear, on one occasion a large seal was observed escaping from the gear provided with the AHD. It is likely that this animal had impaired hearing. The existence of deaf animals, especially large males, has been reported earlier (Varjopuro 2003).

The applicability test showed that only solar-panel powered AHD units on rafts worked properly during the whole fishing seasons and survived several storms (wind speed reaching up to $15 \mathrm{~m} / \mathrm{s}$ and wave height $2 \mathrm{~m}$ ). It can be concluded that it is possible to use them under the typical fishing conditions of the central and northern Baltic Sea. Moreover, it is possible to transport the rafts to the safety of harbours before more severe weather conditions occur. This was done on one occasion during our study in site $\mathrm{D}$, where the coast is very open to winds. The under-water power cable is also a good solution but is limited to deployments close to the coast where electricity is available. Finally, a battery solution does not seem to be viable due to the high energy consumption of AHDs on the market today.

\section{CONCLUSIONS}

Based on the interviews with fishermen, it was calculated that the economic loss caused by seals to the Estonian coastal fisheries was around 0.9 million euros in 2009. With the aim of mitigating seal impact, Acoustic Harassment Devices powered by solar panels were tested. The conclusion is that they provided sufficient protection against the seal attacks. The issues addressed in this study are important with respect to the ongoing discussions about the possibility of the coastal fisheries' co-existence with seals. The results obtained here support the application of AHDs for increased catch landings. Hence, there is an economic incentive to maintain the purchase of AHDs in the list of eligible items for support by the European Maritime and Fisheries Fund in Estonia. From 2017 onwards, Estonian fishermen can get support up to $80 \%$ of the cost of the AHD equipment.

\section{ACKNOWLEDGEMENTS}

This study was supported by the European Fisheries Fund through the target financing obtained from the Estonian Ministry of Agriculture. We are very thankful to Esa Lehtonen for valuable comments on the paper. The publication costs of this article were covered by the Estonian Academy of Sciences.

\section{REFERENCES}

Fjälling, A. 2005. The estimation of hidden seal-inflicted losses in the Baltic Sea set-trap salmon fisheries. ICES J. Mar. Sci., 62(8), 1630-1635.

Fjälling, A., Wahlberg, M. and Westerberg, H. 2006. Acoustic harassment devices reduce seal interaction in the Baltic salmon-trap, net fishery. ICES J. Mar. Sci., 63(9), 17511758.

Graham, I. M., Harris, R. N., Denny, B., Fowden D. and Pullan, D. 2009. Testing the effectiveness of an acoustic deterrent device for excluding seals from Atlantic salmon rivers in Scotland. ICES J. Mar. Sci., 66(5), 860-864. 
Graham, I. M., Harris, R. N., Matejusová, I. and Middlemas, S. J. 2011. Do 'rogue' seals exist? Implications for seal conservation in the UK. Anim. Conserv., 14(6), 587-598.

HELCOM 2020. https://portal.helcom.fi/meetings/EG\%20MA MA\%2014-2020-774/MeetingDocuments/Outcome\%20of \%20EG\%20MAMA\%2014-2020.pdf

Hemmingsson, M., Fjälling, A. and Lunneryd, S.-G. 2008. The pontoon trap: Description and function of a seal-safe trapnet. Fish. Res., 93(3), 357-359.

Jacobs, S. R. and Terhune, J. M. 2002. The effectiveness of acoustic harassment devices in the Bay of Fundy, Canada: seal reactions and a noise exposure model. Aquat. Mamm., 28(2), 147-158.

Jounela, P., Suuronen, P., Millar, R. B. and Koljonen, M.-L. 2006. Interactions between grey seals (Halichoerus grypus), Atlantic salmon (Salmo salar), and harvest controls on the salmon fishery in the Gulf of Bothnia. ICES J. Mar. Sci., 63(5), 936- 945.

Kauhala, K., Kurkilahti, M., Ahola, M., Herrero. A., Karlsson, O., Kunnasranta, M. et al. 2015. Age, sex and body condition of Baltic grey seals: Are problem seals a random sample of the population? Ann. Zool. Fenn., 52(1-2), 103-114.

Kreivi, P., Siira, A., Ikonen, E., Suuronen, P., Helle, E. and Riikonen, R. 2002. Seal-induced damage to salmon trap net fishery in the year 2001. Kalatutkimuksia, 185 (in Finnish).

Königson, S., Fjälling, A. and Lunneryd. S.-G. 2007. Grey seal induced catch losses in the herring gillnet fisheries in the northern Baltic. NAMMCO Sci. Publ., 6, 203-213.

Königson, S., Lunneryd, S.-G., Stridh, H. and Sundqvist, F. 2009. Grey seal predation in cod gillnet fisheries in the Central Baltic Sea. J. Northwest Atl. Fish. Sci., 42, 41-47.

Königson, S., Fjälling, A., Berglind, M. and Lunneryd, S.-G. 2013. Male gray seals specialize in raiding salmon traps. Fish. Res., 2013, 148, 117-123.

Lehtonen, E. and Suuronen, P. 2004. Mitigation of seal-induced damage in salmon and whitefish trapnet fisheries by modification of the fish bag. ICES J. Mar. Sci., 61(7), 11951200.

Lunneryd, S. G., Fjälling, A. and Westerberg, H. 2003. A largemesh salmon trap: a way of mitigating seal impact on a coastal fishery. ICES J. Mar. Sci., 60(6), 1194-1199.

Mate, B. R. and Harvey, J. T. 1986. Acoustical deterrents in marine mammal conflicts with fisheries. In Proceedings of Workshop, Newport, OR, USA, February 17-18, 1986. Oregon Sea Grant, ORESU-W-86-001.
Oksanen, S. M., Ahola, M. P., Lehtonen, E. and Kunnasranta, M. Using movement data of Baltic grey seals to examine foraging-site fidelity: implications for seal-fishery conflict mitigation. Mar. Ecol. Prog. Ser., 2014, 507, 297-308.

Sainsbury, J. C. 1996. Commercial Fishing Methods: an Introduction to Vessels and Gears. 3rd ed. Wiley, Hoboken, NJ.

Suuronen, P. and Lehtonen, E. 2012. The role of salmonids in the diet of grey and ringed seals in the Bothnian Bay, northern Baltic Sea. Fish. Res., 125-126, 283-288.

Svels, K., Salmi, P., Mellanoura, J. and Niukko, J. The impacts of seals and cormorants experienced by Baltic Sea commercial fishers. Natural resources and bioeconomy studies 77/2019. https:/jukuri.luke.fi/bitstream/handle/10024/ 544854/luke_luobio_77_2019.pdf?sequence=1\&isAllowed=y

Vanhatalo, J., Vetemaa, M., Herrero, A., Aho, T. and Tiilikainen, R. 2014. By-catch of grey seals (Halichoerus grypus) in Baltic fisheries - A Bayesian analysis of interview survey. PLoS One, 9(11), e113836.

Varjopuro, R. 2003. Conflicts between protected species and fisheries: social science research and policy approaches. TemaNord, 525.

Varjopuro, R. 2011. Co-existence of seals and fisheries? Adaptation of a coastal fishery for recovery of the Baltic grey seal. Mar. Policy, 35(4), 450-456.

Vetemaa, M., Eschbaum, R. and Saat, T. 2006. The transition from the Soviet system to a market economy as a cause of instability in the Estonian coastal fisheries sector. Mar. Policy, 30(6), 635-640.

Waldo, Å., Johansson, M., Blomquist, J., Jansson, T., Königson, S., Lunneryd, S-G. et al. 2020. Local attitudes towards management measures for the co-existence of seals and coastal fishery - A Swedish case study. Mar. Policy, 118, 104018 .

Westerberg, H., Fjälling, A. and Martinsson, A. 2000. Sealinduced damage in Swedish fishery. Description and cost calculation based on logbook statistics and journal keeping in 1996-1997. Fiskeriverket rapport, 3, 3-38 (in Swedish).

Westerberg, H., Lunneryd, S.-G., Wahlberg, M. and Fjälling, A. 2006. Reconciling fisheries activities with the conservation of seals through the development of new fishing gear: a case study from the Baltic fishery - grey seal conflict. In Proceedings of the American Fisheries Society Symposium, 2006, pp. 587-597.

\title{
Hülgekahjud Eesti kalanduses ning hüljeste akustiline peletamine mõrrapüügis
}

\author{
Markus Vetemaa, Ulvi Päädam, Arne Fjälling, Mehis Rohtla, Roland Svirgsden, Imre Taal, \\ Aare Verliin, Redik Eschbaum ja Lauri Saks
}

Eelmise sajandi absoluutse madalseisuga võrreldes on viimastel aastakümnetel Läänemere hallhüljeste Halichoerus grypus arv kümnekordistunud, mis on tekitanud järjest kasvavaid probleeme kalandusele. Käesoleva teadustöö raames küsitleti 151 Eesti rannakalurit eesmärgiga summeerida kõik otsesed ja kaudsed kahjud. Selgus, et 2009. aastal oli hüljeste tekitatud kahju rannapüügile umbes 0,9 miljonit eurot. Hülgekahjude leevendamise võimaluste uurimiseks testiti hülgepeleteid (Lofitech). Uuringus on esitatud kahjude kalkulatsioonid eri püügivahendite ja maakondade kaupa, samuti on võrreldud saake hülgepeletitega varustatud ning varustamata lõkspüünistes. Tulemused näitavad, et hülgepeletid pakuvad imetajate rünnakute vastu piisavat kaitset ja on seega efektiivsed ning nende soetamist tuleks riiklike vahenditega toetada. 